\title{
DAMPAK PENEBANGAN HUTAN TERHADAP BENCANA BANJIR DI KAWASAN CAGAR ALAM PEGUNUNGAN CYCLOOP
}

\author{
Alfasis Romarak $\mathbf{P}^{1}$, I Made Astra ${ }^{2}$, Agung Purwanto ${ }^{3}$ Nadiro $^{4}$ \\ 1,2,3,4) Program Studi PKLH-UNJ Jakarta \\ e-mail: alfasis47@gmail.com,profmadeastraimade@gmail.com, agungpurwanto@unj.ac.id, \\ nadiro@unj.ac.id
}

\begin{abstract}
Abstrak
Tujuan penelitian ini adalah ingin mengetahui : (1) Bagaimana dampak penebangan hutan bagi konservasi cagar alam Pegunungan Cycloops terhadap bencana banjir bagi penduduk Kota Sentani dan Jayapura, (2) Mengapa migran lokal asal pegunungan Tengah Papua ingin bermigrasi ke Jayapura dan cenderung bertempat tinggal dan berladang di sekitar lereng Pegunungan Cycloops.

Metode yang digunakan dalam penelitian ini adalah dekriptif kualitatif, yaitu mencari informasi melalui wawancara mendalam terhadap tokoh adat, migran dan penduduk yang bertempat tinggal di sepanjang lereng pegunungan Cycloops, juga melakukan wawancara terhadap lembaga swadaya masyarakat yang kerkecimpung langsung dalam masalah konservasi alam di Papua. Hasil penelitian menunjukkan bahwa (2) dampak penebangan hutan pada konervasi cagar alam alam hutan Pegunungan Cycloops sangat merusak/mengganggu dalam hal ketersediaan air bersih, banjir karena tindakan manusia telah mengalami degradasi, sehingga berakibat terhadap dampak negatif pada kelangsungan hidup manusia, (2) Penduduk migran asal luar Kota Jayapura masuk dan berpacu bersama penduduk asli sekitar Pegunungan Cycloops berupaya mempertahankan hidup dengan cara memangkas, menebang hutan di sekitar Pegunungan Cycloops untuk sesuai ubi. Hutan di sekitar Pegunungan Cycloops pun terganggu. Lereng-lerengnya banyak berubah menjadi lahan perdagangan.
\end{abstract}

Kata Kunci: Penebangan Hutan, Konservasi Cagar Alam, Ketersediaan Air Bersih.

\begin{abstract}
The purpose of this study is to find out: (1) How is the impact of logging for the conservation of the Cycloop Mountains nature reserve on flood disasters for the residents of Sentani and Jayapura City, (2) Why local migrants from the Central mountains of Papua want to migrate to Jayapura and tend to live and farm. around the slopes of the Cycloops Mountains. The method used in this research is descriptive qualitative, namely seeking information through in-depth interviews with traditional leaders, migrants and residents living along the slopes of the Cycloops mountains, as well as conducting interviews with non-governmental organizations that are directly involved in nature conservation issues in Papua. The results showed that (2) the impact of logging on the conservation of the Cycloops Mountains forest nature reserve is very damaging/disturbing in terms of the availability of clean water, flooding due to human actions has been degraded, resulting in a negative impact on human survival, (2) Population Migrants from outside the city of Jayapura entered and raced with the indigenous people around the Cycloops Mountains to try to survive by cutting down the forest around the Cycloops Mountains for sweet potatoes. The forest around the Cycloops Mountains was disturbed. Many of its slopes have turned into commercial areas.
\end{abstract}

Keywords: Deforestation, Conservation of Nature Reserves, Availability of Clean Water. 


\section{PENDAHULUAN}

Kawasan hutan merupakan kawasan penting sebagai keberlangsungan makhluk hidup. Selain berfungsi sebagai paru-paru dunia, hutan dianggap 'rumah' bagi berbagai ekosistem untuk menjaga kestabilan lingkungan. Adanya pembangunan di berbagai bidang mempengaruhi terjadinya kerusakan hutan yang mengakibatkan terganggunya keseimbangan alam dan dianggap sebagai malapetaka bencana lingkungan secara global.

Hutan merupakan tanah luas yang ditumbuhi pepohonan. Hutan berguna dalam menjaga keseimbangan lingkungan bagi manusia. Hutan dikategorikan berdasarkan jenis pohon yang ada dalam hutan. Ada hutan pinus karena jenis pohon dalam hutan tersebut adalah pinus begitu juga hutan jati karena mayoritas pohon dalam hutan adalah jati. Pepohonan dalam hutan mempunyai banyak fungsi diantaranya adalah: menahan laju erosi tanah, menyerap karbondioksida, menambah unsur hara tanah, pelindung spesies mahluk hidup tertentu, penyimpan air hujan dan sumber air, mampu mengurangi kecepatan angin dan lain sebagainya. wilayah Indonesia terdiri dari hutan baik itu hutan lind ung, suaka alam dan hutan wisata, hutan produksi terbatas dan tetap serta hutan produksi dapat dikonversi (Muhammad Adji Fatur Nugraha, Fahrizal, Iskandar.). Secara garis besar fungsi hutan dapat dikelompokkan menjadi 4 yaitu fungsi ekologis, hidrologis, ekonomis dan kultural. Untuk itu hutan sangat bermanfaat dalam menjaga keseimbangan ekologis di negara kita.

Indonesia adalah negara kepulauan terbesar di dunia, yang mengalokasikan 63\% atau seluas 120,6 juta hektar daratannya, sebagai Kawasan Hutan1, sedangkan sisanya sekitar 37\% merupakan Areal Penggunaan Lain (APL)2. Di samping itu, sekitar 5,3 juta hektar dari perairan wilayah Indonesia telah ditetapkan sebagai Kawasan Konservasi Perairan yang pengelolaannya dimandatkan kepada Kementerian Lingkungan Hidup dan Kehutanan. Kawasan hutan dan kawasan konservasi perairan ditunjuk/ditetapkan berdasarkan Keputusan Menteri Lingkungan Hidup dan Kehutanan tentang Luas Kawasan Hutan dan Kawasan Konservasi Perairan Indonesia. Sampai dengan Desember 2017, luas total kawasan hutan dan kawasan konservasi perairan sekitar 125,9 juta hektar (Kementerian Lingkungan Hidup \& Kehutanan Republik Indonesia, 2018:44). Jumlah luas kerusakan hutan tersebut cenderung diakibatkan oleh penebangan liar (illegal logging) dan kebakaran hutan.

Banjir merupakan bencana alam paling sering terjadi, baik dilihat dari intensitasnya pada suatu tempat maupun jumlah lokasi kejadian dalam setahun yaitu sekitar $40 \%$ di antara bencana alam yang lain. Bahkan di beberapa tempat, banjir rmerupakan rutinitas tahunan. Lokasi kejadiannya bisa diperkotaan atau pedesaan, negara sedang berkembang atau negara maju sekalipun (E.Suherlan, 2001 dalam suprayogi 2017).

Sedangkan menurut Ditjen Penataan Ruang Departemen PU, banjir adalah aliran air di permukaan tanah yang relatif tinggi dan tidak dapat ditampung oleh saluran drainase atau sungai sehingga melimpah ke kanan dan ke kiri serta menimbulkan genangan atau aliran dalam jumlah melebihi normal dan mengakibatkan kerugian.Bencana banjir merupakan peristiwa atau rangkaian peristiwa yang mengancam dan mengganggu kehidupan dan penghidupan masyarakat sehingga mengakibatkan timbulnya korban jiwa manusia, kerusakan lingkungan, kerugian harta benda, dan dampak psikologis (Mistra, 2007).

Secara umum banjir disebabkan oleh 2 faktor utama, yaitu faktor alam dan faktor manusia. Faktor alam yang menyebabkan terjadi banjir diantaranya curah yang terlalu tinggi, berkurangnya daerah resapan air di kawasan hulu dan pendangkalan sungai akibat erosi.Semua tidak terlepas dari fungsi utama hutan sebagai pengendali daur air. banyak pengaruh-pengaruh penutupan hutan yang jelas terhadap fenomena iklim. Hutan berperan sebagai pengatur tata air, dimana sebagian curah hujan akan disi mpan sebagai air tanah dan akan dikeluarkan saat musim kemarau, disamping dimanfaatkan sendiri oleh tumbuhan dalam metabolismenya. Bertambahnya debit sungai pada daerah aliran sungai yang ditebang, disebabkan oleh terhentinya transpirasi tumbuhan (Jurnal Hutan Lestari. 2015). ketebalan dan luasnya kanopi hutan, serta lantai hutan yang padat serta sistem perakaran yang dalam menentukan pengaruh besar terhadap air. Selain itu faktor manusia yang tidak peka terhadap lingkungan juga menjadi factor penyebab terjadinya banjir. Kurangnya kesadaran dalam mengelola sampah serta perambaan hutan serta bangunan illegal di daerah resapan serta Daerah Aliran Sungai dapat menjadi penyebab terjadinya banjir. 
Kondisi ini seperti yang terjadi di wilayah kawasan cagar alam Pegunungan Cycloop yang sejajar dengan Kota Sentani Kabupaten Jayapura yang merupakan ibu Kota Kabupaten Jayapura, dimana dilalui oleh Daerah Aliran Sungai yang sudah mati karena pepohonan/hutan di bagian hulunya telah habis ditebang terutama beberapa sungai besar yang melintasi beberapa wilayah pemukiman di Kota Sentani yang bagian hulunya dari kawasan cagar alam Cycloops. Akibat pembukaan lahan perkebunan liar oleh penduduk lokal asal pegunungan tengah Papua yang semakin marajela dan berpindah-pindah tempat meyebabkan berkurangnya hutan. Kondisi ini diperparah dengan aktivitas penebangan hutan secara liar yang dilakukan oleh masrayakat lokal asal Pegunungan Tengah Papua maupun masyarakat lokal dari waktu ke waktu. Akibat dari perambahan hutan tersebut dapat menyebabkan banjir apabila curah hujan yang turun sangat tinggi. Pada tanggal 16 Maret 2019 wilayah Kota Sentani yang daerah belakangnya berhadapan langsung dengan Pegunungan Cycloops untuk pertama kalinya yang diterjang banjir bandang yang megakibatkan kerugian bagi masyarakat, berupa rumah dan harta benda yang hilang disapu bersih banjir juga nyawa manusia yang melayang akibat ganasnya banjir yang menyapu bersih tanpa pandang bulu. Selain itu juga terdapat kerugian harta benda seperti kendaraan warga dan juga hewan ternak yang banyak mati. Pada bencana banjir kali ini tergolong lebih besar dampaknya dari pada banjir sebelumnya yang diperkirakan pernah terjadi sekitar berapa puluh tahun sebelumnya. Selain dampak pada nyawa manusia, bencana banjir ini juga mengakibatkan rusaknya beberapa jembatan dalam kota Sentani. Dampak dari banjir ini mengakibatkan pula warga menjadi kesulitan mengakses air bersih.

Bencana banjir pada tahun 2019 disinyalir sebagai akibat dari pembukaan lahan dan penebangan hutan di wilayah hulu sehingga mengakibatkan sungai-sungai yang melintasi kota Sentani penuhi oleh material seperti kayu dan juga sedimentasi sehingga sangat mudah meluap ketika terjadi hujan dengan intensitas cukup tinggi. Karena itu, penulis tertarik mengkaji dampak penebangan hutan terhadap bencana banjir di Kawasan Cagar Alam Cycloop Kabupaten Jayapura.

\section{METODE}

Penelitian ini merupakan penelitian lapangan (field research) dan pendekatan kualitatif dengan fokus penelitiannya adalah Dampak Penebangan Hutan Terhadap Bencana Banjir di Kawasan Cagar Alam Pegunungan Cycloops Kabupaten Jayapura. Penelitian kualitatif adalah suatu proses penelitian yang memberikan pemahaman berdasarkan metodologi yang bersifat menyelidiki suatu fenomena sosial yang ada di dalam masyarakat, Menurut Umar suatu pendekatan penelitian yang hasil penelitiannya tidak diolah dalam bentuk kalkulasi angka-angka, melainkan dengan cara menyampaikan pemikiran atau wawasan peneliti terkait dengan data yang diambil dari subjek yang diteliti.

Penelitian ini tergolong dalam penelitian lapangan (field research). Field research adalah pencarian data dilapangan, karena penelitian yang dilakukan menyangkut dengan persoalan atau kenyataan dalam kehidupan nyata, bukan pemikiran abstrak yang terdapat dalam teks-teks atau dokumen-dokumen tertulis atau terekam. Hal ini di karenakan peneliti harus memiliki pengetahuan tentang kondisi, situasi, dan pergolakan hidup partisipan dan masyarakat yang diteliti.

Lokasi yang digunakan dalam penelitian ini adalah di Kawasan Cagar Alam Pegunungan Cycloop yang berhadapan langsung dengan Kota Sentani Kabupaten Jayapura.

Alasan saya mengambil atau memilih Kawasan Cagar Alam Cycloops karena lokasinya yang dekat dengan titik bencana banjir bandang. Juga daerah ini juga sering terjadi banjir dan salah satu faktor terjadinya banjir disebabkan oleh penebangan hutan di bagian hulu sungai yang marak terjadi. Pada tahun 2007, telah terjadi banjir sebanyak 1 kali dan dalam tahun 2019 terjadi banjir bandang yang mengakibatkan kerugian, kerusakan pada harta benda dan rusaknya tanaman dan hilangnya hewan ternak masyarakat yang terendam dan terseret oleh banjir. Banjir yang terjadi pada maret tahun 2018 disebabkan oleh para penebang (Operator sensor) yang melakukan penebangan dan perladangan berpindah secara terus menerus di lereng pegunungan cycloops sehingga ketika curah hujan yang turun sangat tinggi di bagian hulu, terjadi potensi banjir yang sangat besar yang memporandak-porandakan beberapa lokasi pemukiman dan infrastruktur jalan dan jembatan di Kota Sentani dan sekitarnya. 
Penebangan hutan bukan saja dilakukan oleh orang asli (Pribumi) melainkan juga penebangan hutan dilakukan oleh migran lokal asal Pegunungan Tengahi yang mendiami lereng pegunungan cycloops mulai dari Doyo hingga kawasan Ifar Gunung. Para migran ini biasanya menemui pemilik hutan untuk bernegoisasi/membicrakan kontrak hutan yang mereka inginkan untuk dikelola. Kebiasaan ini dilakukan secara sepihak tanpa memikirkan dampak sosialnya

\section{HASIL DAN PEMBAHASAN}

\section{Dampak yang Terjadi Akibat Aktivitas Penebangan Hutan di Pegunungan Cycloops} Debit Air Berkurang

Bukti bahwa debit air di kawasan Cycloops berkurang adalah dapat diketahui dari volume air yang ditemukan pada sejumlah sungai-sungai kecil yang membelah beberapa kawasan permukiman di Kota Jayapura dan di sekitar Kota Sentani. Sungai-sungai kecil tersebut sebagian besar telah kering kerontang. Alur sungainya hanya dapat teraliri ketika turun hujan. Bila tidak turun hujan, maka aluralur sungai tersebut kering. Sedangkan sungai lainnya yang masih menampakan debit airnya adalah sungai-sungai yang sepanjang bantarannya kurang tersentuh oleh ulah manusia yang bertempat tinggal di sekitarnya.

Meskipun demikian, debit air sungai-sungai tersebut tidak sederas seperti biasanya ketika tidak turun hujan, debit airnya hanya menetes dan membentuk formasi aliran yang berbentuk garis dari hulu hingga ke muara. Alirannya tidak mampu melebar ke kiri ataupun ke kanan alur dalam sungai. Dampak langsungnya adalah sumber air bersih untuk kebutuhan mandi, cuci dan masak menjadi berkurang.

Dari banyaknya sumber mata air yang disebutkan di atas, fakta menunjukkan bahwa beberapa sumber mata air yang dikelola pemerintah Kota dan Kabupaten Jayapura untuk menyuplai air bersih ke lokasi pemukiman penduduk di Kota Jayapura dan sekitarnya adalah Kali Kenandili, Kali Hubai, Kali Kampwolker dan Kali Anafre. Ketiga kali tersebut menjadi urat nadi pengelolaan air bersih oleh pemerintah setempat melalui Perusahaan Daerah Air Minum (PDAM Kabupaten dan Kota Jayapura) dengan membangun bak penampungan air bersih pada lokasi tertentu yang ditetapkan sebagai lokasi dibangunnya bak penampung air bersih.

Sumber mata air lainnya tidak terdata karena telah berubah fungsi sebagai lokasi perladangan, kawasan pemukiman, penggalian batu dan pasir sehingga debit airnya terus menyusut.

\section{Kurangnya Pasokan Air Bersih}

Terancamnya hutan Cycloops berdampak pula terhadap perkembangan suplay air bersih ke setiap kawasan pemukiman penduduk di kota Jayapura dan Sentani. Jumlah dan persebaran penduduk yang tidak merata ditambah dengan potensi suplay air bersih yang tidak stabil sepanjang tahunnya terus mengurangi kemudahan suplay air bersih ke rumah warga, terlebih ketika aktivitas di sepanjang lereng pegunungan Cycloops turus merambat ke arah puncak.

Konsekuensinya, sejumlah kawasan pemukiman tertentu di kota Jayapura dan Sentani seseringkali dalam masa-masa tertentu mengalami krisis air bersih. Migrasi masuk yang terus meningkat kemudian menambah ruang gerak pemukiman. Sempitnya pemukiman kemudian tidak didukung dengan ijin Mendirikan Bangunan (IMB), yang jelas.

IMB yang tidak jelas ini kemudian memarakkan jaringan pipa air minum ilegal antara warga. Pasokan air bersih yang dulunya mengalir secara stabil, kemudian berubah secara periodik. Penduduk yang stabil volume sumber bersihnya, terpaksa dalam kesempatan tertentu harus antri menimba air bersih di rumah-rumah warga yang menerima langsung air bersih dan pipa induk PDAM. Di satu sisi, demi kepentingan pendapatan asli daerah kota, pemenintah cenderung mengutamakan investorinvestor lokal, nasional dan internasional, yang membangun pusat perbelanjaan, hotel, dengan memasang jaringan air minum yang tetap sehingga, memperkecil volume air ke masyarakat lapisan bawah. Imbasnya, pemukiman pada kawasan tertentu tidak memperoleh air minum secara wajar.

Disini jelas bahwa potensi sumber air tersebut sudah terinveksi di bagian hulunya, sehingga kapasitas alirannya yang sudah diatur untuk dialirkan ke rumah-rumah warga terbatas penggunanya. 
Banjir

Pola perladangan berpindah, penebangan kayu secara ilegal serta aktivitas perburuan di hutan Cycloops, berpotensial dalam menuai banjir di Kota Jayapura dan Sentani dan sekitarnya. Hutan dibabat secara bebas sebingga air mudah mengalir ke daerah-daerah yang rendah permukaan tanahnya, terutama ke alur-alur sungai. Demikian pula pengerukan pasir dan pengambilan batu di pinggiran bantaran sungai/kali yang terus berlangsung sehingga air mudah menembus bebatuan yang kecil dan potensial untuk menimbulkan banjir.

Sudah tercatat dalam kasus-kasus banjir di Kota Sentani, Abepura dan Jayapura, bahwa sungaisungai di sepanjang jalan Raya Abepura Sentani, diantaranya potensial menimbulkan banjir. Sungai Makenway di Desa Nolokia Kampung Harapan, Sungai Kenandili di Sentani Kota, dikenal sebagai sungai-sungai yang langganan banjir bila hujan deras. Kerugian infrastruktur, kerugian material warga berupa rumah-rumah penduduk tak terhitung berapa banyaknya. Bila dipisahkan sesuai karakteristik kerugian yang ditimbulkan oleh banjir, infrastuktur jalan dan jembatan diperkirakan bisa mencapai ratusan hingga milyaran rupiah.

\section{Menurunnya Derajat Kesehatan Masyarakat}

Menipisnya sumber air bersih dari hutan Cycloops, ternyata tidak hanya berpengaruh terhadap kehidupan flora dan fauna yang hidup di dalanmya, tetapi berdampak luas pula terhadap derajat kesehatan penduduk yang menerima sumber air yang berasal darinya, seperti menurunnya derajat kesehatan masyarakat. Kurang tersedianya air berpengaruh terhadap aktivitas manusia setiap hari. Misalnya air untuk kepentingan mandi, cuci dan masak. Kawasan pemukiman yang sulit memperoleh air bersih biasanya rentan terhadap penyakit kulit dan muntaber.

Layanan-layanan publik seperti rumah sakit seseringkali mengeluhkan tentang masalah air bersih. Rumah Sakit Umum Daerah Jayapura, Abepura misalnya, seringkali krisis air bersih, sehingga terpaksa keluarga pasien harus membawa air bersih dari rumah ke ruang menginap guna kebutuhan mandi, cuci dan pembersihan sisa kotoran pasien.

Di satu sisi layanan kesehatan sebagai salah satu konsumen publik membutuhkan kesan dan ketelitian dalam menangani suatu gejala penyakit kronis tertentu. Penyakit-penyakit tertentu seperti pembedahan/operasi usus buntu, kanker rahim, kanker payudara dan sebagainya sangat membutuhkan air bersih untuk kebutuhan minum, masak bagi pasien, pembersihan ruang nginap pasien, air mandi pasien, penyemprotan bunga di halaman rumah sakit dan sebagainya, sehingga dengan ketidakstabilan air bersih sangat berpengaruh terhadap derajat kesehatan masyarakat.

\section{Ketersediaan Air Bersih bagi Kebutuhan Transportasi Laut yang Terbatas}

Menurunnya debit air di hutan Cycloops temyata berpengaruh juga terhadap aktivitas pelayaran di kawasan timur Indonesia, khususnya di Kota Jayapura. Fakta membuktikan bahwa suplai air bersih ke kawasan pelabuhan kapal Jayapura, kini mulai menurun drastis.

Setiap kapal yang menyinggahi pelabuhan tersebut terbatas perolehan air bersihnya, baik kapal gudang (kapal embargo), maupun kapal penumpang. Seringkali manajemen kapal maupun penumpang kapal mengeluhkan tentang rnenipisnya persediaan air bersih di kapal-kapal tersebut.

Beberapa contoh kasus Kapal Penumpang (Kapal Putih), ketika melakukan pelayaran dari pelabuhan Jayapura keluar Papua, menyerukan kepada seluruh penumpangnya bahwa karena menipisnya persediaan air bersih di Pelabuhan Jayapura, maka bak penampung air mandi pada kapal tersebut tidak terisi. Kasus tersebut menunjukkan bahwa debit air pada hutan Cycloops berkurang sehingga berdampak pada luasan distribusinya di pelabuhan kapal Jayapura.

Ada kecenderungan bahwa keterbatasan air bersih untuk menunjang setiap pelayaran yang menyinggahi pelabuhan tersebut berada pada tahap stasioner. Jumlah penduduk dengan mobilitasnya yang cukup tinggi kemudian tidak mampu mengimbangi ketersediaan sumber daya air di sekitamya. 


\section{Pemboran Sumur-Sumur Resapan}

Meradangnya hutan Cycloops berpengaruh terhadap ketersediaan sumber air bersih secara merata bagi penduduk di Kota dan Kabupaten Jayapura. Berkurangnya suplai air bersih, berpengaruh terhadap kebutuhan pemenuhan air bersih.

Berbagai fakta diberbagai belahan kota-kota di seluruh permukaan bola bumi ini telah mengalami krisis air. Sungai-sungai semakin dangkal karena hutan di bagian hulu telah tiada. Pemboran sumur pun dilakukan. Tanya disadari terjadi kehampaan air dalam tanah menyebabkan tanah menjadi labil dan bangunanpun menjadi rusak. Kota-kota di daerah pantai, airnya kemudian menjadi asin, karena air laut merembes masuk ke berbagai wilayah karena kehampaan.

Demikian pula air sungai tersebut telah banyak berkontaminasi dengan kandungan zat-zat beracun yang berasal dari sisa sampah pembuangan manusia. Kesehatan manusia tidak akan terjamin, karena kandungan air yang terkontaminasi oleh unsur-unsur beracun tertentu. Manusia membayar mahal untuk membangun industri penyaringan air bersih.

\section{SIMPULAN}

Dampak penebangan hutan pada konservasi cagar alam hutan Pegunungan Cycloops sangat tidak baik bagi ketersediaan air, karena tindakan manusia telah mengalami degradasi, sehingga berakibat adanya dampak negatif pada kelangsungan hidup manusia. Hutan primer yang dijarah manusia untuk kepentingan pengerukan pendapatan mengakibatkan debit air di daerah tersebut mengalir di atas permukaan tanah dan tak tersimpan di dalam tanah yang pada akhirnya ketersediaan air bagi penduduk sangat kurang. Sungai makin dangkal karena hutan di bagian hulu telah tiada. Pemboran sumur pun dilakukan. Tanpa disadari terjadi kehampaan air dalam tanah sehingga menyebabkan tanah menjadi labil dan bangunan pun menjadi rusak. Kota-kota di daerah pantai, airnya kemudian menjadi asin, karena air laut merembes masuk ke berbagai wilayah karena kehampaan. Demikian pula air sungai tersebut telah banyak terkontaminasi dengan kandungan zat-zat beracun yang berasal dari sisa sampah pembuangan manusia. Kesehatan manusia tidak terjamin, karena kandungan air yang terkontaminasi oleh unsur-unsur beracun tertentu. Manusia harus membayar mahal untuk membangun industri penyaringan air bersih.

Penduduk migran asal luar Kota Jayapura masuk dan berpacu bersama penduduk asli sekitar Pegunungan Cycloops berupaya mempertahankan hidup dengan cara memangkas, menebang hutan di sekitar Pegunungan Cycloops untuk sesuap ubi. Hutan di di sekitar Pegunungan Cycloops pun terganggu. Lereng-1erengnya banyak berubah menjadi lahan perladangan. Penduduk di sekitar lereng-lereng tersebut hanya memikirkan bagaimana caranya memperoleh beberapa butir ubi dengan mengorbankan hutan di lereng Pegunungan Cycloops, tanpa disadari bahwa telah mengorbankan beberapa ton air yang setiap harinya yang dibutuhkan penduduk Kota Jayapura. Penduduk dibeberapa bagian Kota Jayapura telah mulai berteriak kekurangan air dan penduduk di bagian lainnya berteriak banjir, tapi suara mereka seolaholah tertelan gemuruh pohon yang bertumbangan dan ketidakpedulian pihak terkait.

\section{SARAN}

Berdasarkan kesimpulan di atas, maka pemerintah harus senantiasa bertindak melarang penduduk menebang hutan dan harus menanam kembali menghijaukan hutan yang disertai sanksi-sanksi berat berdasar perundang-undangan lingkungan hidup yang berlaku.

\section{DAFTAR PUSTAKA}

Arief Rosyidie: Banjir Fakta dan Dampaknya, Serta Pengaruh dari perubahan guna lahan.jurnal perencanaan wilayah dan Kota, vol. 24. No 3, Desember 2013, 241-246.

Artikel rumah 123 com.senin:22/06/2020 ( .megenal jenis banjir yang terjadi di Dunia).

B .Wasis. 2003.Dampak Kebakaran Hutan dan Lahan terhadap Kerusakan Tanah.repasitori.ITB .AC.ID..diakses 17 agustus 2020.(Bogor Agricultural University)

Departemen Kehutanan dan Perkebunan, 1999. Buku Panduan Kehutanan Indonesia. Dephutbun RI. Jakarta. 
Departemen Kehutanan dan Perkebunan, 1999.Undang-undang Nomor 41 Tahun 1999 Tentang Kehutanan. Dephutbun RI. Jakarta.

Departemen Kehutanan, 2001. Keputusan Menteri Kehutanan No. 70/KptsI I/2001 Tentang Penetapan Kawasan Hutan, perubahan status dan fungsi kawasan hutan. Jakarta.

Departemen Kehutanan, 2002. Peraturan Pemerintah RI No. 34 tahun 2002 Tentang Tata Hutan dan Penyusunan Rencana Pengelolaan Hutan, Pemanfaatan Hutan dan Penggunaan Kawasan Hutan. Jakarta

E. Suherlan 2001.Sprayogi 2017.analisi tingkat kerawana banjir dikabupaten Sampan mengunakan metode oferlai dgn scoring berbasis sistem informasi geografis. Jurnal Geo Desi UNDIP Volume 6, NO 1, Thn 2017( ISSN: 2337-845 X)

Izzatul kamila dan Nawiyato.Kerusakan Hutan dan muculnya gerakan konservasi dilereng gunung lamongan, klakah 1999-2013.3 september 2020

Jurnal Geodesi Undip/ Januari 2017.Analisis Tingkat Kerawanan Banjir Di Kabupaten Sampang Menggunakan Metode Overlay Dengan Scoring Berbasis Seitem Informasi Geografis. (Kurnia Darmawan, Hani’ah, Andri Suprayogi).Jurnal Hutan Lestari ( 2015).vol. 3 (2): 217226

Kementerian Lingkungan Hidup dan Kehutanan Republik Indonesia. 2018. Status Hutan \& Kehutanan Indonesia 2018.

Legal Sebastian. Pendekatan Pencegahan dan Penanggulangan Banjir.sumber: dinamika Teknik Sipil, Volume 8, nomor 2 juli 2008 htt:)//docs.goole com.

Manan S. 1997. Hutan, Rimbawan, dan Masyarakat. Bogor: IPB Press.

Mistra tahun 2007.www.eprints.w.ums.com...akses 15 agustu 2020

Sugiyono. 2011. Metode penelitian kuantitatif. Kualitatif. Dan R\&D. Bandung: Alfabeta.

Wairata Julian 2010. Kerusakan hutan akibat pembukaan lahan kebun diuncen baru waena prunas 3. Jurnal 10 Septermber 2020.

Wasis Basuki, 2019. Kejahatan Kehutanan (Illegal Logging, Kebakaran Hutan Dan Lahan, Kerusakan Hutan Dan Perambahan Hutan.Workshop dan Lokakarya Forum Ahli Dalam Penyelesaian Sengketa Lingkungan Hidup Hidup Melalui Pengadilan Batam. Penyelenggara, Kementerian Lingkungan Hidup Dan Kehutanan Republik Indonesia.

Wulan, Yuliana Cahya dkk, 2004.Analisa Konflik Sektor Kehutanan di Indonesia tahun 19972003. CIFOR: Jakarta.

Zains, A. S. 1996. Hukum lingkungan Konservasi Hutan. Penerbit Rineka Cipta. Jakarta 